\title{
PRODUCTION OF AMBARELLA SEEDLINGS TREATED WITH INDOLE BUTYRIC ACID AND IRRIGATED WITH REUSED WATER
}

\author{
Jorge Luís Fabricio Queiroz ${ }^{1}$, Miguel Ferreira Neto ${ }^{1}$, Francisco Vanies da Silva Sá ${ }^{1 *}$, Francisco de Queiroz Porto \\ Filho $^{1}$, Yuri Bezerra de Lima ${ }^{1}$, Pollyana Mona Soares Dias ${ }^{1}$ \\ ${ }^{1}$ Federal Rural University of Semi-Arid - UFERSA, Department of Agronomic and Forest Sciences, Mossoró, Rio Grande do Norte - RN, \\ Brazil, vanies_agronomia@hotmail.com*
}

Received for publication: 15/03/2018 - Accepted for publication: 24/07/2019

\begin{abstract}
Resumo
Produção de mudas de cajaraneira tratadas com ácido indolbutírico e irrigadas com água residuária. As espécies do gênero Spondias, como a cajaraneira, são propagadas prioritariamente por partes vegetativas. Entretanto, para que haja o enraizamento é necessário o emprego de reguladores vegetais. Além dos aspectos relacionados à propagação, a disponibilidade de água de boa qualidade para produção de mudas em regiões semiáridas é um fator limitante. Com isso, objetivou-se por meio deste trabalho avaliar o enraizamento de estacas semi-herbáceas de cajaraneira, utilizando-se diferentes concentrações de IBA veiculado em solução e talco, irrigadas com diferentes concentrações de efluente doméstico tratado. $\mathrm{O}$ experimento foi realizado em viveiro telado com $50 \%$ de sombreamento em delineamento inteiramente casualizado em esquema fatorial $4 \mathrm{x}$ 4 constituído de quatro doses do efluente doméstico tratado (EDT) diluído em água de abastecimento (AA) $[\mathrm{E} 1=0 \%$ do EDT $(100 \%$ AA - testemunha); E2 $=33,3 \%$ do EDT $(66,7 \%$ de AA); E3 = 66,7\% do EDT (33,3\% de AA) e E4 = $100 \%$ do EDT (0\% AA)] utilizadas na irrigação diariamente, e quatro manejos de diluição de IBA $(\mathrm{M} 1=$ testemunha sem IBA, M2 = IBA veiculado em água à $6.000 \mathrm{mg} \mathrm{L}-1, \mathrm{M} 3=\mathrm{IBA}$ veiculado em álcool (70\%) à $4.000 \mathrm{mg} \mathrm{L}-1$ e M4 = IBA veiculado em talco à $5.000 \mathrm{mg}$ L-1), com quatro repetições. O efluente doméstico tratado é viável para irrigação de mudas de cajaraneira na forma diluída ou concentrada. O uso de $5.000 \mathrm{mg} \mathrm{L-1}$ de IBA veiculado a talco é o manejo satisfatório para propagação de mudas de cajaraneira por meio de estacas semi-herbáceas.

Palavras-chave: Spondias cytherea, efluente doméstico tratado, reuso de água, estaquia, regulador vegetal.
\end{abstract}

\begin{abstract}
Species of the genus Spondias, such as ambarella, are propagated primarily by vegetative parts. However, for planting it is necessary to use plant regulators. In addition to propagation related aspects, the availability of good quality water for seedling production in semi-arid regions is a limiting factor. The objective of this work was to evaluate the rooting of semi-herbaceous cuttings of ambarella using different concentrations of IBA conveyed in solution and talc, irrigated with different concentrations of treated domestic effluent. The experiment was carried out in a nursery with $50 \%$ shade in a completely randomized design in a $4 \times 4$ factorial scheme consisting of four doses of treated domestic effluent (EDT) diluted in water supply [E1 $=0 \%$ of EDT (100\% AA - control); E2 $=33.3 \%$ of EDT ( $66.7 \%$ of AA); E3 $=66.7 \%$ of EDT (33.3\% of AA) and $\mathrm{E} 4=100 \%$ of EDT $(0 \%$ AA) $]$ used in daily irrigation and four IBA dilution managements $(\mathrm{M} 1=$ control without IBA, M2 = IBA carried in water at $6,000 \mathrm{mg} \mathrm{L}-1, \mathrm{M} 3=\mathrm{IBA}$ delivered in alcohol $(70 \%)$ at 4,000 $\mathrm{mg}$ L-1 and M4 = IBA in Talc at $5000 \mathrm{mg} \mathrm{L}-1$ ), with four replicates. The treated domestic effluent is viable for irrigation of ambarella seedlings in its diluted or concentrated. The use of 5,000 mg L-1 of IBA delivered to talc is management satisfactory for the propagation of seedlings of ambarella by means of semi-herbaceous cuttings.

Keywords: Spondias cytherea, treated domestic effluent, water reuse, cutting, growth regulator.
\end{abstract}

\section{INTRODUTION}

Ambarella (Spondias cytherea Sonn), also known in Portuguese as "cajá-mango", "taperebá-do-sertão" and "cajá-anão", belonging to the Anacardiaceae family, is a tropical fruit tree in domestication, exploited for its commercial value and the organoleptic characteristics of its fruits, mainly by extractivism, besides offering great advantages for the drought polygon in Northeastern Brazil, because it does not require much water for its productive cycle (CARVALHO et al., 2008).

Currently, the expansion of this species is restricted by the lack of technologies, from propagation to fruit processing. As far as propagation is concerned, Almeida et al. (2017a) indicated vegetative propagation by cuttings or grafting as the best alternative for this species due to the low viability of its seeds. However, according to some authors, the existing knowledge about propagation by cuttings is insufficient to recommend this technique for an effective commercial-scale seedling production system (GOMES et al., 2005). Several

FLORESTA, Curitiba, PR, v. 49, n. 4, p. 725 - 734, out/dez 2019.

Queiróz, J. L. F. et.al.

ISSN eletrônico 1982-4688

DOI: $10.5380 /$ rf.v49 i 4.58443 
studies have shown the efficacy in the propagation by cuttings using indole butyric acid (IBA) in Spondias species (GOMES et al., 2005; RIOS et al., 2012; ALMEIDA et al., 2017a), but there is still no consensus about the ideal dose and application management of the plant regulator.

In addition to the aspects related to the vegetative propagation of this species, the availability of goodquality water for seedling production in semiarid regions is a limiting factor and may affect plant growth (COSTA et al., 2012). Thus, the technology of water reuse presents itself as one of the most suitable solutions for the sustainable development of this region. Initiatives related to the reuse of domestic wastewater have been the subject of discussion in the Agrarian Reform Settlements in the Brazilian semiarid region, as is the case of the infrastructure for sewage collection, treatment and reuse built in the Milagre Settlement Project (SP) in the municipality of Apodi, Rio Grande do Norte (RN), which had satisfactory results based on the Brazilian guidelines for agricultural use with restriction for leafy vegetables and fresh consumption, according to Reinaldo et al. (2012) and Batista et al. (2013). The sewage collected from the residences underwent preliminary treatment by means of septic tanks, followed by anaerobic filters, and was subsequently used to irrigate different agricultural crops such as: cashew (Anacardium occidentale L) (COSTA et al., 2012), maize (Zea mays L.) (COSTA et al., 2014), cowpea (Vigna unguiculata (L.) Walp.) (Rebouças et al., 2010), seedlings of pepper (Capsicum baccatum L. var. pendulum) and okra (Abelmoschus esculentus L.) (OLIVEIRA et al., 2012) and seedlings of watermelon (Citrullus lanatus Thumb. Mansf.) and tomato (Solanum lycopersicum L.) (COSTA et al., 2013).

In view of the above, the use of wastewater makes it possible to ensure agricultural production resulting in an alternative source of water for agricultural crops, besides being a source of organic matter and nutrients, with potential use for the production of high-quality, low-cost fruit seedlings (ALMEIDA et al., 2012). Thus, this study aimed to evaluate the rooting of semi-herbaceous cuttings of ambarella using different concentrations of IBA in solution and in talc, irrigated with different concentrations of treated domestic effluent.

\section{MATERIAL AND METHODS}

The study was conducted in the period from November 2016 to February 2017, in a nursery with a 50\% shade net, at the Department of Environmental and Technological Sciences of the Federal Rural University of the Semi-Arid Region (UFERSA), East Campus, in Mossoró-RN, located at $5^{\circ} 11^{\prime} \mathrm{S}, 37^{\circ} 20^{\prime} \mathrm{W}$ and $18 \mathrm{~m}$ altitude.

Cuttings were collected using a machete, pruning scissors and a pocketknife in the early morning hours of November 18, 2016, from three adult plants with great vigor and vegetative development which were at the end of the vegetative rest, without leaves, with swollen buds and without any attack of pest or disease. According to Tosta et al. (2014), the material was standardized with length of $20 \mathrm{~cm}$ and mean diameter of $9.0 \mathrm{~mm}$. Cold chamber with temperature close to $20^{\circ} \mathrm{C}$ was used to store the vegetative material for $24 \mathrm{~h}$ until the experiment began, in order to minimize its dehydration and oxidation.

The experiment was carried out in a completely randomized design in a $4 \mathrm{x} 4$ factorial scheme consisting of four doses of treated domestic effluent (TDE) diluted in public-supply water (PSW) $\left[\mathrm{E}_{1}=0 \% \mathrm{TDE}\right.$ (100\% PSW - control); $\mathrm{E}_{2}=33.3 \% \mathrm{TDE}(66.7 \% \mathrm{PSW}) ; \mathrm{E}_{3}=66.7 \% \mathrm{TDE}(33.3 \% \mathrm{PSW})$ and $\mathrm{E}_{4}=100 \% \mathrm{TDE}(0 \%$ PSW)], which were used for daily irrigation, and four IBA dilution managements $\left(\mathrm{M}_{1}=\right.$ control without IBA, $\mathrm{M}_{2}$ $=$ IBA conveyed in water at $6,000 \mathrm{mg} \mathrm{L}^{-1}, \mathrm{M}_{3}=\mathrm{IBA}$ conveyed in alcohol at 4,000 $\mathrm{mg} \mathrm{L}^{-1}$ and $\mathrm{M}_{4}=\mathrm{IBA}$ in talc at $5,000 \mathrm{mg} \mathrm{L}^{-1}$ ), with four replicates, with 6 usable cuttings per plot.

For the preparation of the waters used in irrigation, according to treatments $E_{1}, E_{2}, E_{3}$ and $E_{4}-$ the public-supply water and the treated domestic effluent came from the water distribution network of the East Campus of UFERSA and from the Sewage Treatment Station of the Milagre SP in Apodi/RN, respectively. Before drawing the effluent for subsequent transport, storage and utilization, a sample was collected for physicochemical analysis (Table 1).

Table 1. Physical-chemical composition of treated domestic effluent collected in the sewage treatment station of PA Milagre, Apodi/RN.

Tabela 1. Composição físico-química de efluente doméstico tratado coletado na estação de tratamento de esgotos domésticos do PA Milagre, Município de Apodi/RN.

\begin{tabular}{|c|c|c|c|c|c|c|c|c|c|c|c|c|}
\hline \multirow{2}{*}{$\begin{array}{c}E C \\
\left(d_{S ~ ~ m^{-1}}\right)\end{array}$} & pH & $\mathbf{C a}$ & Mg & $\mathbf{N a}$ & $\mathbf{K}$ & $\mathbf{C l}$ & $\mathrm{CO}_{3}$ & $\mathrm{HCO}_{3}$ & $\mathbf{R A S}^{*}$ & COD & BOD & TOG \\
\hline & \multicolumn{8}{|c|}{ 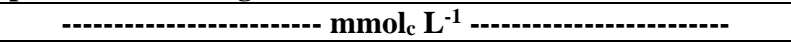 } & \multicolumn{3}{|c|}{---- mg L L-1 --- } & $\mathrm{mg} \mathrm{L}^{-1}$ \\
\hline 1.12 & 6.97 & 0.92 & 1.92 & 3.26 & 0.70 & 3.55 & - & 6.70 & 2.80 & 18.75 & 94.00 & 1.81 \\
\hline
\end{tabular}

EC - Electrical conductivity; $\mathrm{pH}$ - Hydrogen ionic potential; $\mathrm{Ca}$ - Calcium; $\mathrm{Mg}$ - Magnesium; $\mathrm{Na}$ - Sodium; $\mathrm{K}$ - Potassium; $\mathrm{Cl}$ - $\mathrm{Chloro}$; $\mathrm{CO} 3$ - Carbonate; $\mathrm{HCO}_{3}$ - Bicarbonate; RAS - Relationship of Sodium Adsorption; COD - Chemical Oxygen Demand; BOD - Biochemical Oxygen Demand; and TOG - Oils and Greases. CE - Condutividade elétrica; pH - Potencial hidrogeniônico; Ca - Cálcio; Mg - Magnésio; $\mathrm{Na}$ - Sódio; $\mathrm{K}$ - Potássio; $\mathrm{Cl}$ - Cloro; $\mathrm{CO}_{3}$ - Carbonato; $\mathrm{HCO}_{3}$ - Bicarbonato; RAS - Relação de Adsorção de Sódio; DQO - Demanda Química de Oxigênio; DBO - Demanda Bioquímica de Oxigêncio; e TOG - Óleos e Graxas. 
After preparation, the waters were stored in plastic containers with capacity for $100 \mathrm{~L}$, one for each studied proportion between water and effluent, and properly protected to avoid evaporation, entry of rainwater and contamination with materials that could compromise their quality.

The concentrations of indole butyric acid (Table 2) were prepared and diluted in water at $6,000 \mathrm{mg} \mathrm{L}^{-1}$, in alcohol at 4,000 $\mathrm{mg} \mathrm{L}^{-1}$ and dispersed in talc at 5,000 $\mathrm{mg} \mathrm{L}^{-1}$, as recommended by Rios et al. (2012), Bastos et al. (2014) and Tosta et al. (2014), respectively, with some modifications, because the IBA was prepared on the same day the cuttings were collected and was stored in refrigerator to be used the next day.

Table 2. Concentrations and amounts of indole butyric acid, used to prepare $200 \mathrm{~mL}$ of IBA solution.

Tabela 2. Concentrações e quantidades de ácido indolbutírico, empregados para preparar $200 \mathrm{~mL}$ de solução de IBA.

\begin{tabular}{ccccc}
\hline Treatment & $\mathbf{M}_{\mathbf{1}}$ & $\mathbf{M}_{\mathbf{2}}$ & $\mathbf{M}_{\mathbf{3}}$ & $\mathbf{M}_{\mathbf{4}}$ \\
\hline Concentration $\left(\mathrm{mg} \mathrm{L}^{-1}\right)$ & 0 & 6,000 & 4,000 & 5,000 \\
IBA Amount $^{*}(\mathrm{mg})$ & 0 & 1,200 & 800 & 1,000 \\
\hline
\end{tabular}

*4- (3-Indolyl) Butyric Acid P.S. (S 12 H 13 NO 2), produced by VETEC QUIMICA FINA LTDA, with 98\% purity. Ácido 4-(3-Indolil) Butírico P.S. $\left(\mathrm{S}_{12} \mathrm{H}_{13} \mathrm{NO}_{2}\right)$, produzido pela VETEC QUÍMICA FINA LTDA, com $98 \%$ de pureza.

In the vegetative propagation, prior to planting, the cuttings were immersed in the prepared solutions $\left(\mathrm{M}_{1}, \mathrm{M}_{2}, \mathrm{M}_{3}\right.$ and $\left.\mathrm{M}_{4}\right)$, at $3 \mathrm{~cm}$ depth for 5 seconds, and subsequently planted at $1 / 3$ depth in $0.3-\mathrm{dm}^{3}$ tubes, as recommended by Tosta et al. (2012). These tubes were filled with the commercial substrate Tropstrato ${ }^{\circledR} \mathrm{HT}$, based on pine bark, peat and expanded vermiculite, enriched with macro- and micronutrients (Table 3). Before planting, irrigation had been performed in order to leave the substrate moisture content close to the maximum water holding capacity.

Table 3. Chemical characterization of Tropstrato® HT commercial substrate sample.

Tabela 3. Caracterização química de amostra do substrato comercial Tropstrato ${ }^{\circledR}$ HT.

\begin{tabular}{|c|c|c|c|c|c|c|c|}
\hline \multirow{2}{*}{$\begin{array}{c}\text { EC } \\
\left(d_{S} \mathbf{~ m}^{-1}\right)\end{array}$} & \multirow{2}{*}{$\mathbf{p H}$} & OM & $\mathbf{N}$ & $\mathbf{P}$ & $\mathbf{K}^{+}$ & $\mathrm{Ca}^{2+}$ & $\mathrm{Mg}^{2+}$ \\
\hline & & \multicolumn{2}{|c|}{--- $\mathrm{g} \mathrm{Kg}^{-1}$-.- } & \multicolumn{2}{|c|}{-- $\mathrm{mg} \mathrm{dm}^{-3}$-- } & \multicolumn{2}{|c|}{-- cmol dm dm $^{-3}$} \\
\hline 4.61 & 3.68 & 4.03 & 7.9 & 11.0 & 13.5 & 2.3 & 1.8 \\
\hline
\end{tabular}

EC - Electrical conductivity; pH - Hydrogen ionic potential; OM - Organic matter content; N - Nitrogen; P - Phosphorus; K + - Potassium; $\mathrm{Ca}$ - Calcium and Mg - Magnesium. CE - Condutividade elétrica; pH - Potencial hidrogeniônico; OM - Teor de Matéria Orgânica; N Nitrogênio; P - Fósforo; $\mathrm{K}^{+}$- Potássio; Ca - Cálcio e Mg - Magnésio.

To form a humid microclimate, a transparent plastic bag was placed on each cutting and removed when the cutting began to produce the first shoots. From the planting of the cuttings (November 20), irrigations were performed once a day using a watering can in order to leave the substrate with moisture close to the maximum water holding capacity. Field capacity was determined by conducting a water holding test in ten randomly selected tubes containing the substrate, considering the average value. For the test, water was gradually added to the substrate using a graduated cylinder $(1 \mathrm{~L})$ and the drained water was collected. The total volume of the cylinder $(1 \mathrm{~L})$ and the volume drained were used to calculate, by difference, the volume retained in the substrate, hence obtaining the maximum water holding capacity of the substrate.

At 115 days after cutting propagation, the period in which the seedlings are normally transplanted to the field (Tosta et al., 2014), the following parameters were evaluated: average number of shoots (unit cutting ${ }^{-1}$ ), by counting; average shoot length $(\mathrm{cm})$, using a graduated ruler; average shoot diameter $(\mathrm{mm})$, using a digital caliper; average numbers of leaves (unit cutting ${ }^{-1}$ ), leaflets (unit cutting ${ }^{-1}$ ) and roots (unit cutting ${ }^{-1}$ ), by counting; shoot dry biomass $\left(\mathrm{g}_{\text {cutting }}^{-1}\right)$, root dry biomass $\left(\mathrm{g}\right.$ cutting $\left.{ }^{-1}\right)$, total dry biomass $\left(\mathrm{g} \mathrm{cutting}^{-1}\right)$, obtained by washing the materials, placing them in paper bags, drying in the oven at $65{ }^{\circ} \mathrm{C}$ until constant weight, and weighing on a precision scale; and sprouted cuttings (\%), callused cuttings (\%), rooted cuttings (\%) and sprouted and rooted cuttings $(\%)$, by counting and subsequently conversion to percentage.

The obtained data were subjected to analysis of variance by F test. Tukey test at 0.05 probability level was applied in cases of single significant effect of IBA treatments, whereas a polynomial regression analysis at 0.05 probability level was performed in cases of single significant effect of the different dilutions of treated domestic effluent or the interaction between the studied factors, using the statistical program SISVAR $^{\circledR}$ (FERREIRA, 2011). 


\section{RESULTS}

There was significant influence $(\mathrm{p}<0.05)$ of TDE dilution on the variables percentage of sprouted cuttings $(\% \mathrm{SC})$, percentage of callused cuttings $(\% \mathrm{CC})$, percentage of rooted cuttings (\%RC), percentage of sprouted and rooted cuttings (\%SRC), average shoot length (SL), average number of leaves (NL), average number of leaflets (NLf), average root length (CR), average root volume (RV), shoot dry biomass (SDB), root dry biomass (RDB) and total dry biomass (TDB) of ambarella seedlings (Table 4).

Table 4. Summary of analysis of variance for percentage of cuttings sprouted (SC), percentage of cuttings with callus (CC), percentage of rooted cuttings (RC), percentage of cuttings sprouted and rooted (EBR), average number of sprouts ), average number of shoots (NS), average shoot length (SL), average shoot diameter (SD), average leaf number (NL), average number of leaflets (NLf), average number of roots $(\mathrm{NR})$, average root length (RL), average root volume (RV), shoot dry biomass (SDB), root dry biomass (RDB) and total dry biomass (TDB) of ambarella seedlings submitted to different dilutions of domestic effluent treated and to IBA managements.

Tabela 4. Resumo da análise de variância para porcentagem de estacas brotadas (EB), porcentagem de estacas com calos (EC), porcentagem de estacas enraizadas (ER), porcentagem de estacas brotadas e enraizadas (EBR), número médio de brotações (NB), comprimento médio das brotações (CB), diâmetro médio das brotações (DB), número médio de brotações (NB), comprimento médio das brotações $(\mathrm{CB})$, diâmetro médio das brotações $(\mathrm{DB})$, número médio de folhas $(\mathrm{NF})$, número médio de folíolos (NFo), número médio de raízes (NR), comprimento médio de raízes (CR), volume médio de raízes (VR), biomassa seca da parte aérea (BSPA), biomassa seca das raízes (BSR) e biomassa seca total (BST) de mudas de cajaraneira submetidas a diferentes diluições de efluente doméstico tratado e a manejos de IBA.

\begin{tabular}{|c|c|c|c|c|c|c|}
\hline \multirow{2}{*}{ Sources of Variation } & \multirow{2}{*}{ DF } & \multicolumn{5}{|c|}{ F test significance } \\
\hline & & $\% \mathrm{SC}$ & $\% \mathrm{CC}$ & $\% \mathrm{RC}$ & $\%$ SRC & NS \\
\hline Effluent Treaty (E) & 3 & $0.012 *$ & $0.018 *$ & $0.010^{*}$ & $0.008 *$ & $0.365 \mathrm{~ns}$ \\
\hline IBA Management (M) & 3 & $0.000 *$ & $0.001 *$ & $0.003 *$ & $0.000 *$ & $0.271 \mathrm{~ns}$ \\
\hline $\mathrm{E} \times \mathrm{M}$ & 9 & $0.141 \mathrm{~ns}$ & $0.160 \mathrm{~ns}$ & $0.154 \mathrm{~ns}$ & $0.463 \mathrm{~ns}$ & $0.330 \mathrm{~ns}$ \\
\hline $\mathrm{CV}(\%)$ & - & 15.22 & 22.03 & 30.61 & 33.05 & 20.30 \\
\hline \multirow{2}{*}{ Sources of Variation } & \multirow{2}{*}{ DF } & \multicolumn{5}{|c|}{ F test significance } \\
\hline & & SL & SD & NL & NLf & NR \\
\hline Effluent Treaty (E) & 3 & $0.001 *$ & $0.397 \mathrm{~ns}$ & $0.000^{*}$ & $0.006^{*}$ & $0.513 \mathrm{~ns}$ \\
\hline IBA Management (M) & 3 & $0.002 *$ & $0.420 \mathrm{~ns}$ & $0.056 \mathrm{~ns}$ & $0.108 \mathrm{~ns}$ & $0.000^{*}$ \\
\hline $\mathrm{E} \times \mathrm{M}$ & 9 & $0.339 \mathrm{~ns}$ & $0.279 \mathrm{~ns}$ & $0.195 \mathrm{~ns}$ & $0.099 \mathrm{~ns}$ & $0.059 \mathrm{~ns}$ \\
\hline $\mathrm{CV}(\%)$ & - & 29.89 & 23.94 & 18.31 & 20.91 & 37.78 \\
\hline \multirow{2}{*}{ Sources of Variation } & \multirow{2}{*}{ DF } & \multicolumn{5}{|c|}{ F test significance } \\
\hline & & RL & $\mathbf{R V}$ & SDB & RDB & TDB \\
\hline Effluent Treaty (E) & 3 & $0.020 *$ & $0.026^{*}$ & $0.000^{*}$ & $0.021 *$ & $0.000^{*}$ \\
\hline IBA Management (M) & 3 & $0.435 \mathrm{~ns}$ & $0.042 *$ & $0.074 \mathrm{~ns}$ & $0.170 \mathrm{~ns}$ & $0.005^{*}$ \\
\hline $\mathrm{E} \times \mathrm{M}$ & 9 & $0.271 \mathrm{~ns}$ & $0.232 \mathrm{~ns}$ & $0.722 \mathrm{~ns}$ & $0.475 \mathrm{~ns}$ & $0.862 \mathrm{~ns}$ \\
\hline $\mathrm{CV}(\%)$ & - & 23.95 & 73.66 & 34.89 & 48.29 & 35.65 \\
\hline
\end{tabular}

* - significant at 5\% probability, ns - No Significant up to $5 \%$ probability; CV - Coefficient of Variation; and DF - Degree of Freedom. $*$ significativo a $5 \%$ de probabilidade, ns - Não Significativo até 5\% de probabilidade; CV - Coeficiente de Variação; e DF - Grau de Liberdade.

Regarding the TDE application, there was a linear reduction in the percentage of callused cuttings as the percentage of effluent in the irrigation water increased (Figure 1A). However, despite the higher percentage of callused cuttings, the absence of effluent application led to the lowest percentages of sprouted cuttings $(71.18 \%)$, rooted cuttings (43.35\%) and sprouted and rooted cuttings (40.80\%).

It was also observed that TDE application caused a linear increase in the percentages of sprouted, rooted, and sprouted and rooted cuttings, and the best results were obtained using $100 \%$ TDE in the irrigation of ambarella seedlings (Figures 1B, C and D). Therefore, it is possible to infer that TDE has a positive influence on the production of seedlings and can be used as a satisfactory alternative source of water for the propagation of semi-herbaceous cuttings of ambarella in regions where good-quality water is limited.

There was an increasing linear behavior for the variables average shoot length, average number of leaves, average number of leaflets, average root volume, shoot dry biomass and total dry biomass, as a function of the increase in the proportion of effluent in the irrigation water, with increments of 47.70, 24.11, 47.83, 97.32, 
96.81 and $113.47 \%$, respectively, when comparing plants without TDE application (100\% public-supply water) with those that received $100 \% \mathrm{TDE}$ as irrigation water (Figure 2A, B, C, D, F and H). These results corroborate those observed in the percentage of sprouted and rooted cuttings, so it can be inferred that TDE application is not only feasible for irrigation, but also favors the development of ambarella seedlings propagated by semiherbaceous cuttings.

For the variables average root length and root dry biomass, a quadratic behavior was observed and the highest means were obtained with the doses of 58.44 and $51.50 \%$ of the effluent in the irrigation water (Figure $2 \mathrm{E}$ and $\mathrm{G})$.

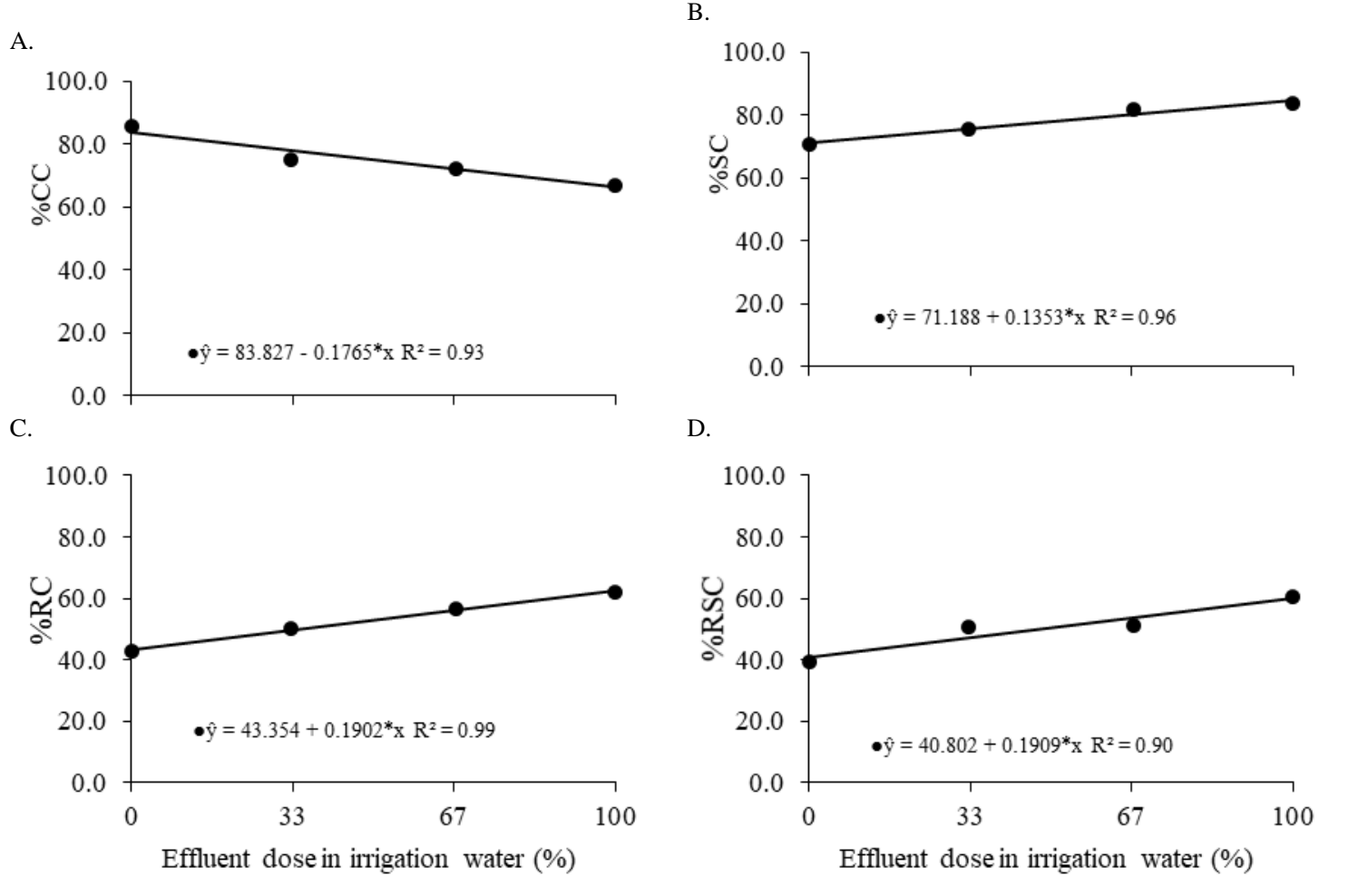

$*=$ significant at $5 \%$ probability $(\mathrm{p}<0.05) . *$ significativo a $5 \%$ de probabilidade $(\mathrm{p}<0,05)$.

Figure 1. Percentage of cuttings with callus, \%CC (A), percentage of cuttings sprouted, \%SC (B), percentage of rooted cuttings, \% RC (C) and percentage of cuttings rooted and rooted, \% RSC ambarella seedlings submitted to different treatments of the treated domestic effluent, at 115 days after cutting.

Figura 1. Porcentagem de estacas com calos, \%CC (A), porcentagem de estacas brotadas, \%SC (B), porcentagem de estacas enraizadas, \%RC (C) e porcentagem de estacas brotadas e enraizadas, \%RSC (D) de mudas de cajaraneira submetidas a diferentes a manejos do efluente doméstico tratado, aos 115 dias após a estaquia.

IBA management had significant influence $(\mathrm{p}<0.05)$ on the variables \%SC, \%CC, \%RC, \%SRC, SL, average number of roots (NR), RV and TDB (Table 4). For the average number of sprouts (NB) and average sprout diameter (SD), there was no significant influence of the studied sources of variation (Table 4).

By analyzing the effect of IBA management on the setting characteristics of the cuttings, it is possible to observe high percentages of callused and sprouted cuttings, which varied from 61.46 to $85.07 \%$ and from 56.60 to $92.36 \%$, respectively (Table 5). Despite the high percentages of callused and sprouted cuttings, the percentages of rooted cuttings and sprouted and rooted cuttings were low in most treatments, and only the treatment $\mathrm{M}_{4}\left(5,000 \mathrm{mg} \mathrm{L}^{-1}\right.$ of IBA in talc) stood out from others, with $69.44 \%$ of rooted cuttings and $67.36 \%$ of sprouted and rooted cuttings (Table 5).

In general, for growth and biomass accumulation, it was observed that the cuttings treated with $\mathrm{M}_{4}$ had the highest average shoot length, average number of roots, average root volume and total dry biomass compared to the other managements (Table 5), which indicates that the use of IBA at the concentration of 5,000 $\mathrm{mg} \mathrm{L}^{-1}$ in talc, was the most promising for the propagation of ambarella plants, leading to greater rooting and growth of the seedlings propagated by semi-herbaceous cuttings. 
A.

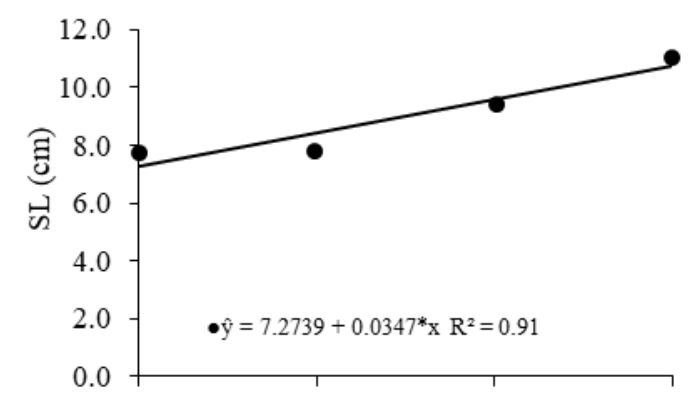

C

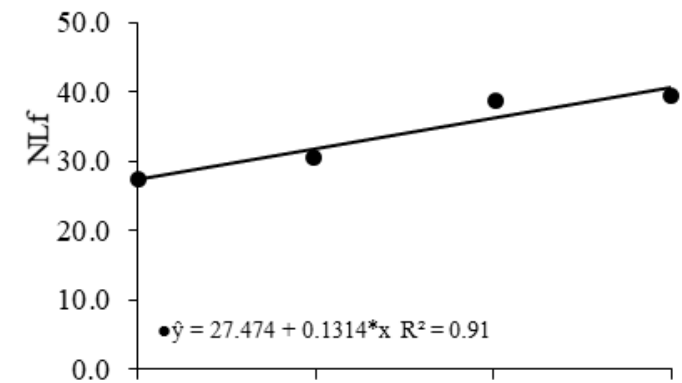

E.

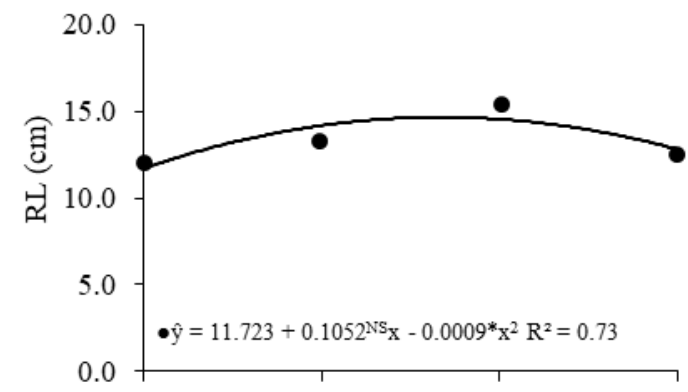

G.

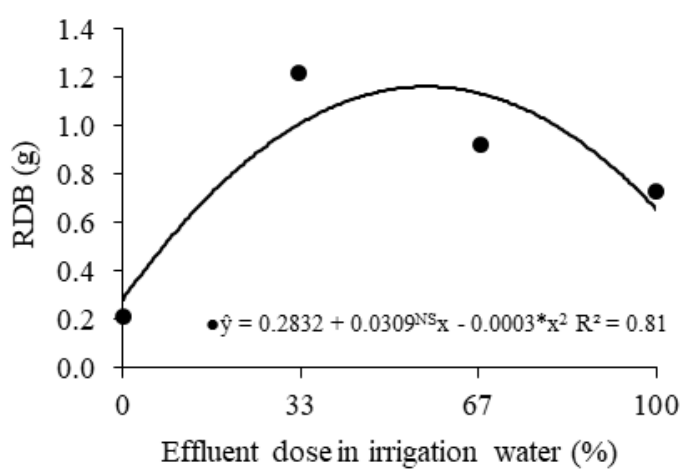

B.

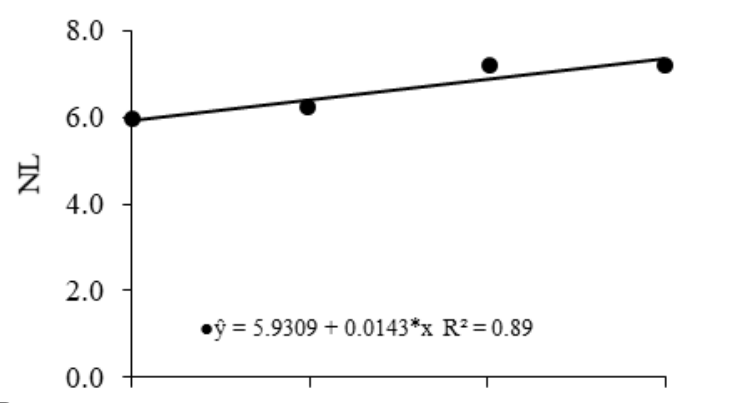

D.

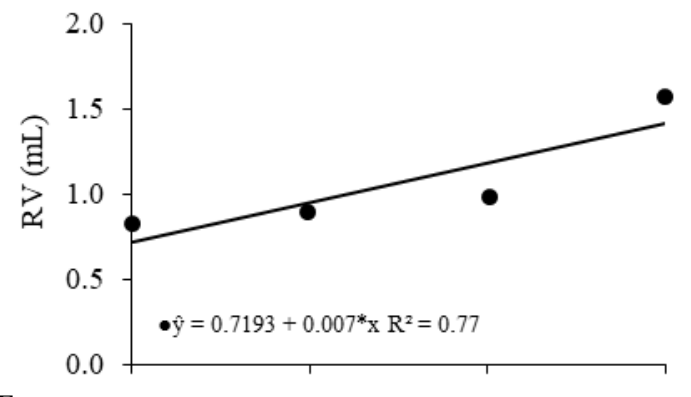

F.

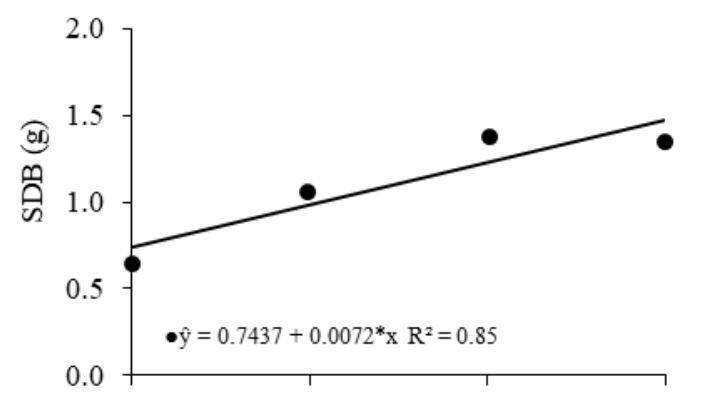

H.

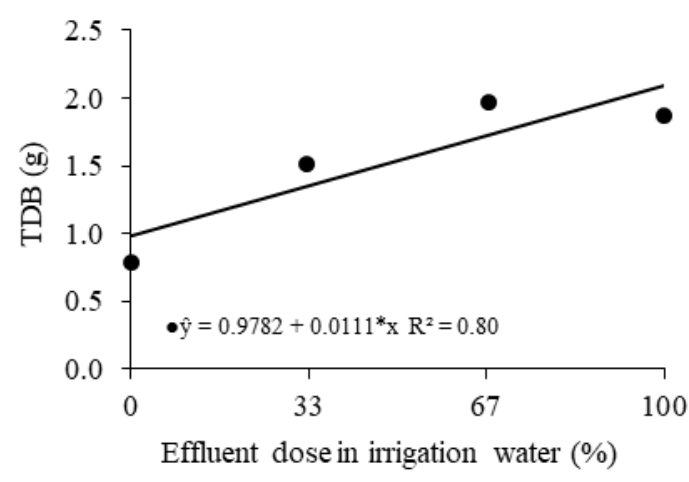

$*$ and NS $=$ significant at $5 \%$ probability $(\mathrm{p}<0.05)$ and not significant, respectively. $* \mathrm{e}^{\mathrm{NS}}=$ significativo a $5 \%$ de probabilidade $(\mathrm{p}$ $<0,05)$ e não significativo, respectivamente.

Figure 2. Average length of shoots, SL (A), mean leaf number, NL (B), mean leaflet number, NLf (C), mean root volume, RV (D), mean root length, RL (E), shoot dry biomass, SDB (F), root dry biomass, RDB (G) and total dry biomass, TDB $(\mathrm{H})$ of ambarella seedlings submitted to different treatments of the treated domestic effluent, at 115 days after the cutting.

Figura 2. Comprimento médio das brotações, SL (A), número médio de folhas, NL (B), número médio de folíolos, NLf (C), volume médio de raízes, VR (D), comprimento médio de raízes, RL (E), biomassa seca da parte aérea, SDB (F), biomassa seca das raízes, RDB (G) e biomassa seca total, TDB (H) de mudas de cajaraneira submetidas a diferentes a manejos do EDT, aos 115 dias após a estaquia. 
Table 5. Average test for percentage of cuttings with callus (\%CC), percentage of cuttings sprouted (\%SC), percentage of rooted cuttings (\%RC), percentage of cuttings rooted and rooted (\%RSC), average length of shoots (SL), mean number of roots (NR), mean root volume (RV) and total dry biomass (TDB) of ambarella seedlings submitted to different IBA managements at 115 th day after cutting.

Tabela 5. Teste de média para porcentagem de estacas com calos (\%CC), porcentagem de estacas brotadas $(\% \mathrm{SC})$, porcentagem de estacas enraizadas (\%RC), porcentagem de estacas brotadas e enraizadas (\%RSC), comprimento médio das brotações (SL), número médio de raízes (NR), volume médio de raízes $(\mathrm{RV})$ e biomassa seca total (TDB) de mudas de cajaraneira submetidas a diferentes manejos de IBA, ao $115^{\circ}$ dia após a estaquia.

\begin{tabular}{ccccc}
\hline IBA Management & \% CC & \%SC & \%RC & \%RSC \\
\hline M1 (control) & $73.96 \mathrm{ab}$ & $80.21 \mathrm{~b}$ & $45.14 \mathrm{~b}$ & $43.75 \mathrm{~b}$ \\
M2 & $79.51 \mathrm{a}$ & $82.64 \mathrm{ab}$ & $48.96 \mathrm{~b}$ & $46.53 \mathrm{~b}$ \\
M3 & $61.46 \mathrm{ab}$ & $56.60 \mathrm{c}$ & $47.92 \mathrm{~b}$ & $43.75 \mathrm{~b}$ \\
M4 & $85.07 \mathrm{a}$ & $92.36 \mathrm{a}$ & $69.44 \mathrm{a}$ & $67.36 \mathrm{a}$ \\
\hline IBA Management & SL $(\mathbf{c m})$ & $\mathbf{N R}$ & $\mathbf{R V}(\mathbf{m L})$ & $\mathbf{T D B}(\mathbf{g})$ \\
\hline M1 (control) & $7.20 \mathrm{c}$ & $1.36 \mathrm{c}$ & $0.60 \mathrm{~b}$ & $1.21 \mathrm{~b}$ \\
M2 & $8.15 \mathrm{bc}$ & $1.69 \mathrm{bc}$ & $1.05 \mathrm{ab}$ & $1.38 \mathrm{ab}$ \\
M3 & $9.86 \mathrm{ab}$ & $2.39 \mathrm{a}$ & $1.38 \mathrm{a}$ & $1.68 \mathrm{ab}$ \\
M4 & $10.81 \mathrm{a}$ & $2.32 \mathrm{ab}$ & $1.16 \mathrm{ab}$ & $1.88 \mathrm{a}$ \\
\hline
\end{tabular}

$\mathrm{M} 1=0 \mathrm{mg} \mathrm{L}^{-1}$ of IBA, M2 $=\mathrm{IBA}$ diluted in water at $6,000 \mathrm{mg} \mathrm{L}^{-1}, \mathrm{M} 3=\mathrm{IBA}$ diluted in alcohol at $4,000 \mathrm{mg} \mathrm{L}^{-1}$ and M4 $=\mathrm{IBA}$ diluted in talc at $5,000 \mathrm{mg} \mathrm{L}^{-1}$. Letter equals in the column do not differ from the Tukey test at $5 \%$ probability. M1 $=0 \mathrm{mg} \mathrm{L}^{-1}$ de IBA, M2 $=$ IBA veiculado em água à $6.000 \mathrm{mg} \mathrm{L}^{-1}, \mathrm{M} 3=\mathrm{IBA}$ veiculado em álcool à $4.000 \mathrm{mg} \mathrm{L}^{-1} \mathrm{e} \mathrm{M} 4=\mathrm{IBA}$ veiculado em talco à $5.000 \mathrm{mg} \mathrm{L}^{-1}$. Letra iguais na coluna não diferem perante ao teste de Tukey a 5\% de probabilidade.

\section{DISCUSSION}

Adopting methods that allow low-quality water, such as wastewater, to be used in irrigation is a practical and convenient solution for reducing water consumption and the negative environmental impacts caused by effluent discharge (ANDRADE et al., 2017). Thus, it is possible to note the importance and viability of using wastewater according to its local availability, as it promotes better agronomic performance and meets the nutritional needs of crops such as cashew (A. occidentale L.) (COSTA et al., 2012), passion fruit (Passiflora edulis Sims) (ALMEIDA et al., 2012), Eucalyptus grandis Hill. ex Maiden (AUGUSTO et al., 2007) and forest species of the Caatinga biome (ARAÚJO et al., 2007; OLIVEIRA et al., 2013; PINTO et al., 2016; ALMEIDA et al., 2017b). Despite the quadratic behavior observed in root system growth, there were no restrictions on shoot growth and no symptoms of toxicity were observed. Thus, the restrictions on root system growth from the estimated dose of $51.50 \%$ of the effluent are possibly related to the greater supply of energy for shoot development, given the conditions of good availability of water and nutrients in the substrate provided by the effluent.

Results similar to the ones observed in the present study have also been reported by Costa et al. (2012) and Almeida et al. (2012), who used TDE in the production of cashew and passion fruit seedlings, respectively. These authors also verified that TDE application led to better results compared to public-supply water. This is explained by the nutritional characteristics of the effluent, since the good nutritional supply is one of the characteristics of the TDE, positively influencing the water and nutritional status of the plant, increasing its growth and influencing the quality of seedlings (REBOUÇAS et al., 2010; PINTO et al., 2016; ALMEIDA et al., 2017b).

Evaluating the production of ambarella seedlings by cuttings, Almeida et al. (2017a) found no influence of IBA doses on their rooting and dry biomass accumulation. According to these authors, the results with the IBA application were quite variable depending on the species, cultivars, dose, cutting immersion time and branch age. Thus, different from the results found by these authors, the application of IBA in talc promoted

FLORESTA, Curitiba, PR, v. 49, n. 4, p. 725 - 734, out/dez 2019. 
promising results in rooting, growth and biomass accumulation in the present study, which indicates that the IBA management form is of fundamental importance for its efficacy in the production of ambarella seedlings. Results similar to those observed in this study were reported for woody cuttings of ambarella by Tosta $e t$ al. (2012), who indicate the dilution of IBA in talc for satisfactory seedling production. However, despite the promising results found by Rios et al. (2012) and Bastos et al. (2012) in the propagation of woody cuttings of ambarella with $6,000 \mathrm{mg} \mathrm{L}^{-1}$ of IBA conveyed in water and 4,000 $\mathrm{mg} \mathrm{L}^{-1}$ of IBA conveyed in alcohol, respectively, the results are not satisfactory in the propagation of semi-herbaceous cuttings of this species.

Souza and Lima (2005) reported that the shoots are formed from organic reserves contained in the cuttings, and true leaves only form if there is production of adventitious roots so that there is a supply of nutrients and water. Rios et al. (2012) added that endogenous factors constitute one of the most serious problems in the production of Spondias seedlings, and it is important to search for auxiliary techniques, such as the use of growth regulators for the success in the rooting of cuttings and the application of synthetic auxin, like IBA.

According to Taiz et al. (2015), IBA is often used to make hormonal balancing, where it causes the increase of the endogenous concentration of auxins in the tissues, accelerating the formation of roots, which induces cell elongation, transforming the physiological activities of the plant. IBA has been used for rooting of cuttings of several tree species, according to Leandro and Yuyama (2008). Hartmann et al. (2011) complement that the use of phytohormones through exogenous application leads to higher percentage, velocity, quality and uniformity of rooting in many species, which reduces the permanence of cuttings in the nursery, thus facilitating the production of seedlings on a commercial scale. However, it is possible to infer that the applications of 6,000 $\mathrm{mg} \mathrm{L}^{-1}$ of IBA conveyed in water $\left(\mathrm{M}_{2}\right)$ and 4,000 $\mathrm{mg} \mathrm{L}^{-1}$ of IBA conveyed in alcohol $\left(\mathrm{M}_{3}\right)$ are inefficient for the rooting of ambarella cuttings, since these treatments did not differ from the control, and the application of 5,000 $\mathrm{mg} \mathrm{L^{-1 }}$ of IBA in talc was the most suitable for the propagation of ambarella seedlings among the treatments studied (Table 5). In practice, there is even greater ease of management of IBA dispersed in talc compared to its dilutions in water or alcohol. In the latter two cases, there is a risk of losses in the agricultural practice of propagation by cuttings.

The lack of interaction between these factors indicated the independence of these sources of variation. Maximum performance in the production of ambarella seedlings can be obtained using the best concentration of TDE, i.e. $100 \%$ of the effluent, and best management of IBA, at concentration of 5,000 $\mathrm{mg} \mathrm{L}^{-1}$ mixed with talc.

\section{CONCLUSIONS}

- Treated domestic effluent can be used to irrigate ambarella seedlings in its diluted or concentrated form, presenting itself as an alternative source of water for irrigation.

- The use of IBA at the concentration of $5,000 \mathrm{mg} \mathrm{L}^{-1}$ in talc is satisfactory for the propagation of ambarella seedlings by means of semi-herbaceous cuttings, besides its greater ease of management compared to treatments in solution.

\section{REFERENCE}

ALMEIDA, J. P. N.; COSTA, L. R.; SAMPAIO, P. R. F.; AZEVEDO, J.; DIAS, N. S. Utilização de esgoto doméstico tratado na produção de mudas de maracujazeiro amarelo. Revista Verde de Agroecologia e Desenvolvimento Sustentável, Mossoró, v. 7, n. 4, p. 69-75, 2012.

ALMEIDA, J. P. N.; LEITE, G. A.; MENDONÇA, V.; CUNHA, P. S. C. F.; ARRAIS, I. G.; TOSTA, M. S. Concentrações de IBA e substratos no enraizamento e vigor de estacas lenhosas de cajaraneira. Revista de Ciências Agrárias, Belém, v. 60, n. 1, p. 11-18, 2017a.

ALMEIDA, J. P. N.; FREITAS, R. M. O.; NOGUEIRA, N. W.; OLIVEIRA, F. A.; FERREIRA, H.; LEITE, M. S. Production of Piptadenia stipulacea (Benth.) Ducke seedlings irrigated with fish farming wastewater. Revista Brasileira de Engenharia Agrícola e Ambiental, Campina Grande, v. 21, n. 6, p. 386-391, $2017 \mathrm{~b}$.

ANDRADE, B. A. S.; LACERDA, P. S. B.; OLIVEIRA, J. L. M. Viabilidade técnica de reuso de efluente gerado do sistema de osmose reversa em uma indústria farmacêutica. Revista Ambiente e Água, Taubaté, v. 12, n. 5, p. 607-707, 2017. 
ARAÚJO, B. A.; DANTA NETO, J.; LIMA, V. L. A.; SANTOS, J. S. Uso de esgoto doméstico tratado na produção de mudas de espécies florestais da caatinga. Princípia, João Pessoa, v. 7, n. 1, p. 48-53, 2007.

AUGusto, C. C.; GUERRINE, I. A.; ENGEL, V. L.; ROUSSEAU, G. X. Utilização de águas residuárias provenientes do tratamento biológico de esgotos domésticos na produção de mudas de Eucalyptus grandis Hill. ex. Maiden. Revista Árvore, Viçosa, v. 31, n. 4, p. 745-751, 2007.

BAstos, L. P., DANTAS, A. C. V. L., COSTA, M. A. P. C., BAStOS, M. J. S. M., ALMEIDA, V. O. Propagação vegetativa de umbu-cajzeira. Enciclopédia Biósfera, Goiânia, v. 10, n. 18, p. 2508-2517, 2014.

BATISTA, R. O.; REINALDO, G. P. B.; FREIRE SEGUNDO, J. M.; LEMOS FILHO, L. C. A; SILVA, P. C. M.; SANTOS, D. B. Sistema ecológico para tratamento de esgoto primário em assentamentos rurais do semiárido brasileiro. Revista Agrarian, Grande Dourados, v. 6, n. 22, p. 438-447, 2013.

CARVALHO, P. C. L.; RITZINGER, R.; SOARES FILHO, W. S.; LEDO, C. A. S. Características morfológicas, físicas e químicas de frutos de populações de umbu-cajazeira no Estado da Bahia. Revista Brasileira de Fruticultura, Jaboticabal, v. 30, n. 1, p. 140-147, 2008.

COSTA, L. R.; GURGEL, M. T.; ALVES, S. M. C.; MOTA, A. F.; AZEVEDO, J.; ALMEIDA, J. P. N. Crescimento de mudas de cajueiro anão precoce irrigado com efluente doméstico tratado. Revista Brasileira de Ciências Agrárias, Recife, v. 7, p. 421-426, 2012.

COSTA, M. S.; Alves, S. M. C.; FERREIRA NETO, M.; BATISTA, R. O.; TORRES, S. B. Avaliação do desempenho de melancia e tomate cereja sob tratamento com efluente doméstico. Engenharia Ambiental, v. 10, suplemento, p. 66-74, 2013.

COSTA, Z. V. B.; GURGEL, M. T.; COSTA, L. R.; ALVES, S. M. C.; FERREIRA NETO, M.; BATISTA, R. O. Efeito da aplicação de esgoto doméstico primário na produção de milho no assentamento Milagres (ApodiRN). Revista Ambiente e Água, Taubaté, v. 9, n. 4, p. 737-751, 2014.

FERREIRA, D. F. Sisvar: a computer statistical analysis system. Ciência e Agrotecnologia, Lavras, v. 35, n. 6, p. 1039-1042, 2011.

GOMES, W. A.; ESTRElA, M. A.; MENDONÇA, R. M. N.; SILVA, S. M.; SOUZA, A. P.; ALVES, R. E. Enraizamento de estacas de umbu-cajazeira (Spondias spp.). Procedings of the Interamerican Society for Tropical Horticulture, Boca Chica, v. 47, n. 1, p. 231- 233, 2005.

HARTMANN, H. T.; KESTER, D. E.; DAVIES JR., F. T.; GENEVE, R. L. Plant propagation: principles and practices. $8^{\text {th }}$ ed. New Jersey: Prentice-Hall, 2011. 915p.

LEANDRO, R. C.; YUYAMA, K. Enraizamento de estacas de castanha-de-cutia com uso de ácido indolbutírico. Acta Amazônica, Manaus, v. 38, n. 4, 597-602, 2008.

OLIVEIRA, J. F.; AlVES, S. M. C.; BATISTA, R. O.; COSTA, M. S.; QUEIROZ, J. L.; LIMA, V. I. A. Avaliação de mudas de sabiá e mororó fertirrigadas com esgoto doméstico tratado. Agropecuária Científica no Semiárido, Patos, v. 9, n. 1, p. 46-52, 2013.

OLIVEIRA, J. F.; ALVES, S. M. C.; FERREIRA NETO, M.; BATISTA, R. O. Efeito da água residuária de esgoto doméstico tratado na produção de mudas de pimenta cambuci e quiabo. Enciclopédia biosfera, Goiânia, V. 8, n. 14, p. 443-452, 2012.

PINTO, J. R. S.; FREITAS, R. M. O.; LEITE, T. S.; OLIVEIRA, F. A.; FERREIRA, H.; LEITE, M. S. Growth of young Tabebuia aurea seedlings under irrigation with wastewater from fish farming. Revista Brasileira de Engenharia Agrícola e Ambiental, Campina Grande, v. 20, n. 6, p. 519-524, 2016.

REBOUÇAS, J. R. L.; DIAS, N. S.; GONZAGA, M. I. S.; GHEYI, H. R.; SOUSA NETO, O. N. Crescimento do feijão-caupi irrigado com água residuária de esgoto doméstico tratado. Revista Caatinga, Mossoró, v. 23, n. 1, p. 97-102, 2010.

REINALDO, G. P. B.; BATISTA, R. O.; SILVA, P. C. M.; LEMOS FILHO, L. C. A.; FERREIRA NETO, M.; SANTOS, D. B. Desempenho de sistema decanto-digestor com filtro biológico seguido por alagado construído e reator solar no tratamento de esgoto doméstico. Revista Ambiente e Água, Taubaté, v. 7, n. 2, p.62-74, 2012.

RIOS, E. S.; PEREIRA, M. C.; SANTOS, L. S.; SOUZA, T. C.; RIBEIRO, V. G. Concentrações de ácido indolbutírico, comprimento e época de coleta de estacas, na propagação de umbuzeiro. Revista Caatinga, Mossoró, v. 25, n. 1, p. 52-57, 2012. 
SOUZA, F. X.; LIMA, R. N. Enraizamento de estacas de diferentes matrizes de cajazeira tratadas com ácido indolbutírico. Revista Ciência Agronômica, Fortaleza, v. 36, n. 2, p. 189-194, 2005.

TAIZ, L.; ZEIGER, E.; MØLLER, I. M.; MURPHY, A. Fisiologia e desenvolvimento vegetal. 6. ed. Porto Alegre: Artmed, 2017. 858p.

TOSTA, M. S., OLIVEIRA, C. V. S., FREITAS, R. M. O., PORTO, V. C. N., NOGUEIRA, N. W., TOSTA, P. A. F. Ácido indolbutírico na propagação vegetativa de cajaraneira (Spondias sp.). Revista Brasileira de Ciências Agrárias, Recife, v. 33, suplemento 1, p. 2727-2740, 2012. 